\title{
The Hydroalumination of Ethylene. A Self-consistent Field Molecular Orbital Study
}

\author{
ODD GROPEN $^{a}$ and ARNE HAALAND ${ }^{b}$
} a Department of Chemistry, Institute of Mathematical and Physical Sciences, University of Tromsø, N-9001
Tromsø, Norway and ${ }^{b}$ Department of Chemistry, University of Oslo, Blindern, Oslo 3, Norway

Self-consistent field molecular orbital calculations have been performed on the reactants and product of the model reaction $\mathrm{H}_{2} \mathrm{AlH}^{*}+\mathrm{H}_{2} \mathrm{C}=\mathrm{CH}_{2} \rightarrow \mathrm{H}_{2} \mathrm{Al}$ $-\mathrm{CH}_{2}-\mathrm{CH}_{2} \mathrm{H}^{*}$, on a symmetric $\pi$-complex formed from the reactants, and on the system at various points along the reaction path.

The reaction is best described as one in which bonds are broken and formed in a concerted manner, proceeding through a four center $\left(\mathrm{Al}, \mathrm{H}^{*}, \mathrm{C}, \mathrm{C}\right)$ transition state. A symmetric $\pi$-complex represents a possible intermediate in the reaction.

The calculated energy of formation of the $\pi$ complex, $\Delta E=-36 \mathrm{~kJ}$, and the calculated energy of the reaction, $\Delta E=-123 \mathrm{~kJ}$, are in good agreement with experimental estimates, but the calculated energy of activation, $E^{\neq}=50 \mathrm{~kJ}$ is considerably higher than the experimental estimate, which is about $5 \mathrm{~kJ}$.

The hydroalumination of an $\alpha$-olefin, eqn. (1), is of great industrial importance as the first step in

$\mathrm{R}_{2}^{\prime} \mathrm{AlH}^{*}+\mathrm{H}_{2} \mathrm{C}=\mathrm{CHR} \rightarrow$

$\mathrm{R}_{2}^{\prime} \mathrm{Al}-\mathrm{CH}_{2}-\mathrm{C}(\mathrm{R}) \mathrm{HH}^{*}$,

Ziegler-catalyzed polymerization of ethylene ( $R$ $=H, R^{\prime}=$ ethyl), and in the dimerization of propene $\left(\mathbf{R}=\right.$ methyl, $\mathbf{R}^{\prime}=\mathrm{n}$-propyl). ${ }^{1}$ The terminal step in the catalytic cycles of both processes consists of the reverse reaction, the $\beta$-elimination of an olefin from a trialkylaluminium compound, ${ }^{1}$ eqn. (2). The

$$
\begin{aligned}
& \mathbf{R}_{2}^{\prime} \mathrm{Al}-\mathrm{CH}_{2}-\mathrm{C}\left(\mathbf{R}^{\prime \prime}\right)\left(\mathbf{R}^{\prime \prime \prime}\right) \mathrm{H}^{*} \rightarrow \\
& \mathbf{R}_{2}^{\prime} \mathrm{All} \mathbf{H}^{*}+\mathrm{H}_{2} \mathrm{C}=\mathrm{C}\left(\mathbf{R}^{\prime \prime}\right) \mathbf{R}^{\prime \prime \prime} .
\end{aligned}
$$

kinetics of both reactions in the gas phase have been extensively studied by Egger and coworkers ${ }^{2}$ who conclude that both reactions proceed through a four center transition state as indicated in Fig. 1c.

As part of their investigations Eggers and coworkers have determined the activation energies, $E_{2}^{\neq}$, for the elimination of ethylene from triethylaluminium, ${ }^{3}$ for the elimination of 1 butene from dimethylbutylaluminium, ${ }^{4}$ and for the elimination of isobutene from triisobutylaluminium: $:^{5}$

$\begin{array}{lll} & E_{2}^{\ddagger}(\mathrm{kJ}) & \Delta H_{2}(\mathrm{~kJ}) \\ \mathrm{Et}_{3} \mathrm{Al} & 126(1) & 122 \\ \mathrm{Me}_{2} \mathrm{n}-\mathrm{BuAl} & 116(2) & 111 \\ \mathrm{i}-\mathrm{Bu}_{3} \mathrm{Al} & 111(3) & 103\end{array}$

The enthalpies of the corresponding reactions, $\Delta \mathrm{H}_{2}$, have been estimated by Smith. ${ }^{6}$ It appears, therefore, that the corresponding hydroalumination reactions (1) are exothermic, $\Delta H_{1}=-\Delta H_{2}$, and proceed with a small activation energy, $E_{1}^{\neq}=E_{2}^{\neq}$ $-\Delta H_{2} \sim 5 \mathrm{~kJ}$.

We have investigated the model reactions

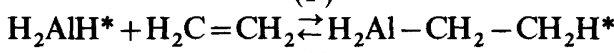

by ab initio molecular orbital calculations in the hope of obtaining more information about the nature of the reaction and geometry and bonding in the transition state. A similar study of the hydroalumination of acetylene has already been published. $^{7}$

\section{COMPUTATIONS}

The calculations were performed under the $\mathrm{LCAO}-\mathrm{MO}-\mathrm{SCF}$ approximation using program 


$$
\begin{aligned}
& \mathrm{H}=\mathrm{Al} \stackrel{1.56 \AA}{-}
\end{aligned}
$$

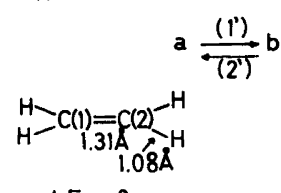

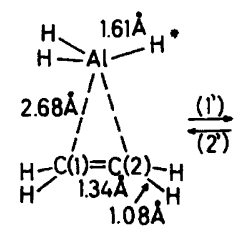

$\Delta E=0$

$\Delta E=-36 \mathrm{~kJ} \mathrm{~mol}^{-1}$

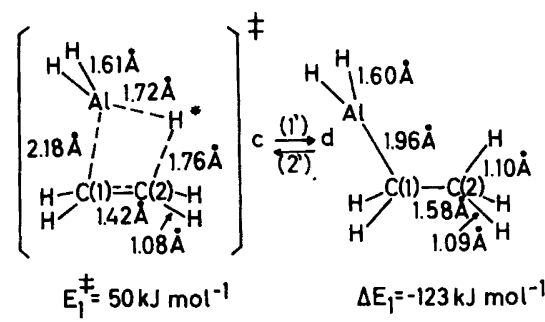

Fig. 1. Bond distances and relative energies of the reactants, products and activated complex of reactions $\left(1^{\prime}\right)$ and $\left(2^{\prime}\right)$. The symmetric $\pi$-complex represents a possible intermediate.

MOLPRO written by Pulay and Meyer. The basis set consisted of $(10,6)$ GTO functions on $\mathrm{Al}$ contracted to $\langle 5,3\rangle,(7,3)$ GTO functions on C contracted to $\langle 3,2\rangle^{8}$ and four GTO functions on $\mathrm{H}$ contracted to $\langle 2\rangle .^{9}$ This set was augmented by a set of d-functions on $\mathrm{Al}^{7}$

The geometries of the two reactants and product of $\left(1^{\prime}\right)$, of a $\pi$-complex formed from the reactants, and of intermediate species with fixed reaction coordinate, were optimized using the force relaxation method of Pulay. ${ }^{10}$

\section{RESULTS AND DISCUSSION}

Reactants and product. The optimal bond distances and valence angles of reactants and product are listed in Table 2. The optimal $\mathrm{Al}-\mathrm{H}$ and $\mathrm{Al}-\mathrm{C}$ bond distances are in good agreement with the experimental values for $\mathrm{H}_{3} \mathrm{AlN}\left(\mathrm{CH}_{3}\right)_{3}{ }^{11}$ and monomeric $\left(\mathrm{CH}_{3}\right)_{3} \mathrm{Al},{ }^{12} 1.56(1)$ and $1.957(3) \AA$, respectively. The $\mathrm{CC}$ and $\mathrm{CH}$ bond distances and valence angles are in reasonable agreement with standard values. The energy of reaction $\left(1^{\prime}\right)$ calculated from the electronic energies of reactants and product, $\Delta E_{1}=-123 \mathrm{~kJ}$, agrees very well with Smith's estimated enthalpies of reaction listed above. We conclude, therefore, that our calculations are reasonably successful in reproducing both the geometries and the relative energies of reactants and product.

The $\pi$-complex. A symmetric $\pi$-complex (Fig. 1b) is found to represent a local minimum on the potential energy surface. The calculated energy of formation of the complex is $\Delta E=-36 \mathrm{~kJ}$. As in the case of the reaction of $\mathrm{H}_{3} \mathrm{Al}$ with acetylene, ${ }^{7}$ this $\pi$-complex represents a possible intermediate, and not the transition state of the reaction.

Dolzine and Oliver ${ }^{13}$ have found that while the average degree of association of tripentylaluminium in freezing cyclohexane is $n=1.80$, the analogous terminal trialkenyl compound, $\left[\mathrm{H}_{2} \mathrm{C}\right.$ $\left.=\mathrm{CH}\left(\mathrm{CH}_{2}\right)_{3}\right]_{3} \mathrm{Al}$, is monomeric $(n=0.99)$ under the same conditions. They suggest that the alkenyl compound achieves valence saturation through intramolecular coordination of one $\mathrm{C}=\mathrm{C}$ bond to the metal. Since the enthalpy of dissociation of the tripentynaluminium dimer is about $62 \mathrm{~kJ} \mathrm{~mol}^{-1},{ }^{14}$ the $\mathrm{Al} \cdots \mathrm{C}=\mathrm{C}$ interaction energy must be at least $-31 \mathrm{~kJ}$, in good agreement with our theoretical estimate.

The reaction coordinate. As in our study of the hydroalumination of acetylene, we selected the perpendicular distance from $\mathrm{H}^{*}$ to the $\mathrm{CC}$ bond axis as the reaction coordinate. ${ }^{7}$ This distance was denoted by $z^{*}$ and varied in steps from its value in the $\pi$-complex, $2.88 \AA$, to its value in the product, $1.04 \AA$. After each step all other structure parameters were reoptimized. The resulting energies are listed in Table 1 and the optimal structure parameters for each step on the way are

Table 1. SCF energies (in atomic units) and energy differences relative to reactants (in $\mathrm{kJ} \mathrm{mol}^{-1}$ ) along the reaction path of $\left(1^{\prime}\right)$. The reaction coordinate, $z^{*}$, is defined as the perpendicular distance from $\mathrm{H}^{*}$ to the $\mathrm{CC}$ bond axis.

\begin{tabular}{lllr}
\hline & $z^{*}(\AA)$ & \multicolumn{1}{l}{$E_{\mathrm{SCF}}$} & $\Delta E_{\mathrm{SCF}}$ \\
\hline Reactants & $\infty$ & -321.2059 & 0 \\
$\pi$-complex & 2.88 & -321.2194 & -36 \\
& 2.00 & -321.2058 & 0 \\
& 1.80 & -321.1936 & +32 \\
Activated & 1.70 & -321.1861 & +52 \\
complex & 1.66 & -321.1867 & +50 \\
& 1.60 & -321.1887 & +45 \\
& 1.50 & -321.1952 & +28 \\
& 1.40 & -321.2032 & +7 \\
Product & 1.20 & -321.2374 & -83 \\
& 1.04 & -321.2527 & -123 \\
\hline
\end{tabular}


Table 2. Selected bond distances (in $\AA$ ) and valence angles (in degrees) at different points along the reaction path of $\left(1^{\prime}\right)$.

\begin{tabular}{lllrrrrrrrrr}
\hline$z^{*}$ & $\begin{array}{l}\infty \\
\text { Reactants }\end{array}$ & $\begin{array}{l}2.88 \\
\pi- \\
\text { complex }\end{array}$ & 2.00 & 1.80 & 1.70 & $\begin{array}{l}1.66 \\
\text { Activated } \\
\text { complex }\end{array}$ & \multicolumn{7}{c}{1.60} & 1.50 & 1.40 & 1.20 & $\begin{array}{l}1.04 \\
\text { Product }\end{array}$ \\
\hline $\mathrm{Al}-\mathrm{H}$ & 1.56 & 1.61 & 1.61 & 1.61 & 1.61 & 1.61 & 1.61 & 1.61 & 1.61 & 1.61 & 1.60 \\
$\mathrm{Al}-\mathrm{H}^{*}$ & 1.56 & 1.63 & 1.61 & 1.62 & 1.76 & 1.72 & 1.90 & 1.93 & 1.96 & - & - \\
$\mathrm{Al}-\mathrm{C}(1)$ & - & 2.68 & 2.68 & 2.47 & 2.17 & 2.18 & 2.06 & 2.06 & 2.06 & 1.95 & 1.96 \\
$\mathrm{C}(1)-\mathrm{C}(2)$ & 1.31 & 1.34 & 1.34 & 1.34 & 1.42 & 1.42 & 1.48 & 1.50 & 1.50 & 1.56 & 1.58 \\
$\mathrm{C}(2)-\mathrm{H}^{*}$ & - & 3.02 & 2.16 & 1.94 & 1.80 & 1.76 & 1.70 & 1.60 & 1.50 & 1.31 & 1.10 \\
$\mathrm{C}(2)-\mathrm{H}$ & 1.08 & 1.08 & 1.08 & 1.08 & 1.08 & 1.08 & 1.08 & 1.07 & 1.07 & 1.08 & 1.09 \\
$\angle \mathrm{HAlH}$ & 120 & 117 & 117 & 117 & 125 & 125 & 120 & 120 & 120 & 120 & 125 \\
$\angle \mathrm{AlC}(1) \mathrm{C}(2)$ & - & 75 & 75 & 77 & 82 & 81 & 84 & 84 & 84 & 92 & 122 \\
$\angle \mathrm{C}(1) \mathrm{C}(2) \mathrm{H}^{*}$ & - & 108 & 112 & 112 & 108 & 109 & 109 & 110 & 112 & 113 & 109 \\
$\angle \mathrm{HC}(1) \mathrm{H}$ & 117 & 116 & 116 & 116 & 118 & 118 & 118 & 118 & 118 & 110 & 109 \\
$\delta^{a}{ }^{*}$ & 0 & 0 & 0 & 0 & 20 & 20 & 30 & 30 & 30 & 45 & 50 \\
\hline
\end{tabular}

${ }^{a} \delta$ is the angle between the $\mathrm{CC}$ bond and the $\mathrm{CH}_{2}$ planes.

listed in Table 2. The highest energies were obtained for $z^{*}=1.7$ and $1.6 \AA$, and a series of calculations involving more careful structure optimization located the saddle point on the potential energy surface, corresponding to the activated complex, at $z^{*}=1.66 \AA$.

Inspection of Table 2 shows that the bond distances $\mathrm{Al}-\mathrm{H}^{*}, \mathrm{Al}-\mathrm{C}$ and $\mathrm{C}-\mathrm{H}^{*}$ change rapidly near the saddle point. The reaction may therefore be described as one in which these bonds are broken and formed in a concerted manner.

The activated complex. A sketch of the activated complex is shown in Fig. 1C. The magnitude of the
$\mathrm{Al}-\mathrm{H}^{*}, \mathrm{Al}-\mathrm{C}, \mathrm{C}-\mathrm{C}$ and $\mathrm{C}-\mathrm{H}$ bond distances confirms Eggers suggestion that the reaction proceeds via a four center transition state. This description is also consistent with the overlap populations listed in Table 3. The structure of the activated complex is similar to the structure of the activated complex in the reaction of $\mathrm{H}_{3} \mathrm{Al}$ with $\mathrm{HC} \equiv \mathrm{CH}$, and - considering the different sizes of $\mathrm{Al}$ and $\mathrm{B}-$ to the activated complex in the reaction of $\mathrm{BH}_{3}$ with $\mathrm{H}_{2} \mathrm{C}=\mathrm{CH}_{2}{ }^{15}$

The calculated activation energy, $E_{1}^{\neq}=50 \mathrm{~kJ}$, is considerably higher than the experimental value, which is about $5 \mathrm{~kJ}$. It is not clear whether the

Table 3. Selected overlap populations and gross atomic populations.

\begin{tabular}{|c|c|c|c|c|}
\hline & Reactants & $\pi$-complex & Activated complex & Product \\
\hline \multicolumn{5}{|c|}{ Overlap populations } \\
\hline $\begin{array}{l}\mathrm{Al}-\mathrm{H}^{*} \\
\mathrm{Al}-\mathrm{C}(1) \\
\mathrm{C}(1)-\mathrm{C}(2) \\
\mathrm{C}(2)-\mathrm{H}^{*}\end{array}$ & $\begin{array}{l}0.80 \\
- \\
1.20 \\
-\end{array}$ & $\begin{array}{r}0.79 \\
0.09 \\
1.02 \\
-0.02\end{array}$ & $\begin{array}{l}0.49 \\
0.34 \\
0.60 \\
0.25\end{array}$ & $\begin{array}{r}-0.02 \\
0.70 \\
0.52 \\
0.80\end{array}$ \\
\hline \multicolumn{5}{|c|}{ Gross atomic populations } \\
\hline $\begin{array}{l}\mathrm{Al} \\
\mathrm{C}(1) \\
\mathrm{C}(2) \\
\mathrm{H}^{*} \\
\mathrm{H}(\mathrm{Al}) \\
\mathrm{H}(\mathrm{C}(1)) \\
\mathrm{H}(\mathrm{C}(2))\end{array}$ & $\begin{array}{r}12.50 \\
6.31 \\
6.31 \\
1.17 \\
1.17 \\
0.84 \\
0.84\end{array}$ & $\begin{array}{r}12.60 \\
6.37 \\
6.36 \\
1.19 \\
1.18 \\
0.78 \\
0.78\end{array}$ & $\begin{array}{r}12.47 \\
6.72 \\
6.27 \\
1.16 \\
1.13 \\
0.76 \\
0.79\end{array}$ & $\begin{array}{r}12.22 \\
6.87 \\
6.40 \\
0.87 \\
1.14 \\
0.82 \\
0.85\end{array}$ \\
\hline
\end{tabular}


difference is due to an inadequate basis or to the neglect of correlation effects.

The gross atomic populations listed in Table 3 indicate that the atomic charges in the activated complex are intermediate between the atomic charges in reactants and product.

We wish to return to a discussion of the regiospecificity of the reaction after having made calculations on methyl derivatives of $\mathrm{H}_{3} \mathrm{Al}$ and ethylene.

\section{REFERENCES}

1. Coates, G. E. and Wade, K. Organometallic Compounds, Menthuen, London 1967, Vol. 1, p. 319.

2. Egger, K. W. Helv. Chim. Acta 55 (1972) 1502 and references therein.

3. Cocks, A. T. and Egger, K. W. J. Chem. Soc. Faraday Trans. 1, 68 (1972) 423.

4. 'Egger, K. W. and Cocks, A. T. Trans. Faraday Soc. 67 (1971) 2629.

5. Egger, K. W. J. Am. Chem. Soc. 91 (1969) 2867.

6. Smith, M. B. J. Organomet. Chem. 76 (1974) 171.

7. Gropen, O. and Haaland, A. Acta Chem. Scand. A 35 (1981) 305.

8. Huzinaga, S. International report.

9. Huzinaga, S. J. Chem. Phys. 42 (1965) 1293.

10. Pulay, P. Mol. Phys. 17 (1969) 197; 18 (1970) 473.

11. Almenningen, A., Gundersen, G., Haugen, T. and Haaland, A. Acta Chem. Scand. 26 (1972) 3928.

12. Almenningen, A., Halvorsen, S. and Haaland, A. Acta Chem. Scand. 25 (1971) 1937.

13. Dolzine, T. W. and Oliver, J. P. J. Am. Chem. Soc. 96 (1974) 1737.

14. Smith, M. B. J. Organomet. Chem. 70 (1974) 13.

15. Nagase, S., Ray, K. N. and Morokuma, K.J. Am. Chem. Soc. 102 (1980) 4536.

Received September 4, 1981. 